\title{
Penggunaan Model Jigsaw dalam Meningkatkan Pemahaman Siswa Kelas 9.3 pada Pelajaran IPS Materi Sejarah di SMPN 16 Bogor Oleh: \\ Gunarti Sukriyatun \\ SMP Negeri 16 Kota Bogor \\ Email:gunartisukriyatun@gmail.com
}

\begin{abstract}
Abstrak
Tujuan penelitian ini untuk mengetahui peningkatan kualitas proses pembelajaran dan hasil belajar Ilmu Pengetahuan Sosial pada siswa kelas 9.3 melalui model Cooperative Learning Jigsaw. Subyek penelitian ini adalah siswa kelas 9.3 SMPN 16 Bogor yang terdiri 38 siswa, dengan komposisi perempuan 23 siswa dan laki-laki 15 siswa. Hasil Penelitian menunjukan bahwa hasil belajar pada siklus I memperoleh nilai 71,32 atau ketuntasan belajar sebesar 50,00\% sedangkan siklus II memperoleh nilai 77,63 atau ketuntasan belajar sebesar 71,05\%; artinya penelitian berhasil. Begitu pula dengan penilaian kualitas pelaksanaan pembelajaran pada siklus I sebesar $86,67 \%$, dan siklus II sebesar 98,33\%. Sedangkan hasil observasi perilaku siswa yang nampak menunjukkan adanya peningkatan dengan perolehan nilai pada siklus I yaitu $57,89 \%$, sedangkan siklus II memperoleh nilai 70,17\%.Berdasarkan hasil penelitian di atas dapat disimpulkan bahwa Penerapan model Cooperative Learning Jigsaw dapat meningkatkan hasil belajar Ilmu Pengetahuan Sosial. Selain itu, dapat meningkatkan kualitas pelaksanaan pembelajaran dan partisipasi serta perilaku siswa.
\end{abstract}

\section{Kata kunci: Hasil belajar, Model Cooperative Learning Jigsaw}

\begin{abstract}
The purpose of this research is to know the improvement of quality learning process and learning outcomes of Social Sciences in class 9.3 through model of cooperative Learning Jigsaw. The population of this research is the class 9.3 SMP N 16 Bogor of elementary students are consisted 38 students, there are 23 female and 15 male students. The result of this research showed in the first cycle get the value 71,32 or completeness study of 50,00\% while in the second cycle get the value 77,63 or completeness study of 71,05\%, it means that the research is successfully. Meanwhile, the assessment of quality in learning on the first cycle is $86,67 \%$ and the second cycle is 98,33\%. In the other hand, the observation result of students behavior are showed an increasing with the value of the first cycle is 57,89\% and in the second cycle is get the value 70,17\%. Based on the result of this research above, it can be conclude that the implementation of Jigsaw by Cooperative Model can improve the result in cognitive learning of Social Sciences. In addition it can improve the quality of learning and participation with students' behavior.
\end{abstract}

Keywords: Results of learning, Cooperative Learning Model Jigsaw 


\section{Pendahuluan}

Materi sejarah merupakan bagian dari mata pelajaran Ilmu Pengetahuan Sosial di sekolah menengah pertama. Namun, dalam pembelajaran IPS biasanya dilakukan secara tematik dan terintegrasi dengan materi, seperti ekonomi, dan geografi. Meskipun demikian, dalam rangka meningkatkan pemahaman siswa terhadap sejarah, guru perlu menambah dan menekankan secara lebih khusus materi sejarah saat mengajar. Disisi lain, pembelajaran IPS materi sejarah dinilai kurang menarik dan membosankan. Materi sejarah terkesan hanya hafalan dan mengunggulkan sisi kognitif saja. Selama pembelajaran, siswa hanya mendengarkan cerita sejarah yang seolah bersifat dogmatis. Dalam proses pembelajaran IPS materi sejarah seringkali pembelajaran hanya bersifat satu arah, yakni guru kepada siswa. Sementara itu, siswa cenderung lebih pasif dan tidak memperhatikan guru ketika mengajar. Kondisi yang demikian membuat prestasi belajar siswa dalam mata pelajaran IPS menurun. Oleh sebab itu, dalam pembelajaran IPS materi sejarah guru perlu menggunakan metode menarik supaya dapat meningkatkan ketertarikan siswa terhadap pembelajaran IPS materi sejarah. Metode yang dipilih oleh guru haruslah metode yang mampu menciptakan komunikasi dua arah, yakni antara guru ke siswa, dan sebaliknya. Dengan demikian, suasana pembelajaran menjadi lebih hidup dan prestasi atau hasil belajar meningkat.

Salah satu materi sejarah yang diajarkan di sekolah menengah pertama adalah materi tentang Orde Baru. Orde Baru adalah Suatu periodesasi kepemimpinan pada masa Presiden Suharto. Kalimat inilah yang sering kita dengar di lingkungan masyarakat maupun lingkungan pendidikan, baik di sekolah dasar maupun di sekolah menengah. Orde Baru bermakna Kembalinya tatanan pemerintahan negara kepada pelaksanaan Pancasila dan Undang Undang Dasar 1945 secara murni dan konsekuen. Hal ini sebagai konsekuensi berakhirnya Masa Orde Lama yang banyak sekali terjadi penyimpangan dari pelaksanaan butir butir dari Sila dalam pancasila dan penyimpangan dari pasal pasal dalam UUD 1945. Dalam konsep-konsep Ilmu Pengetahuan Sosial yang sifatnya abstrak, memerlukan pemahaman yang maksimal dari siswa agar tidak terjadi miskonsepsi terhadap pesan yang terkandung di dalamnya. Oleh karena itu, dalam mempelajari konsep tersebut memerlukan model pembelajaran yang tepat, agar siswa mampu memahami kompetensi dasar yang harus dicapai mengenai konsep-konsep kewarganegaraan.

Model pembelajaran Jigsaw diharapkan agar siswa mampu meningkatkan pemahaman, kualitas dan aktivitas belajar siswa pada pelajaran Ilmu Pengetahuan Sosial ( IPS ), yang dilaksanakan melalui Penelitian Tindakan Kelas (PTK). Tema dalam Penelitian Tindakan ini adalah: "Penggunaan Cooperative Learning Model Jigsaw Dalam Upaya Meningkatkan Pemahaman Siswa Pada Pelajaran Ilmu Pengetahuan Sosial Tentang Berakhirnya Orde Baru dan Lahirnya Reformasi”. Untuk melaksanakan 
pembelajaran IPS di atas, digunakan model diskusi yaitu penggunaan Cooperative Learning Jigsaw. Melalui pembelajaran Jigsaw, diharapkan akan tercipta "Pembelajaran Aktif, Kreatif, Efektif dan Menyenangkan (PAKEM)" khususnya pada mata pelajaran Ilmu Pengetahuan sosial ( IPS ). Hal itu sejalan dengan pendapat Oemar Hamalik (2011:27) yang mengatakan bahwa ada tiga alternatif pendekatan yang dapat digunakan dalam pembelajaran, yaitu : a. Pendekatan yang berpusat pada mata pelajaran,dimana metode yang digunakan adalah metode lama yaitu ceramah, b. Pendekatan yang berpusat pada peserta didik, dimana metode yang digunakan adalah pembelajaran aktif baik secara individual maupun kolaboratif, dan c. Pendekatan yang berorientasi pada kehidupan masyarakat, dimana metode yang digunakan adalah karyawisata, narasumber, kerja lapangan, survei dan lain lain.

Jigsaw yang artinya gergaji ukir adalah salah satu model pembelajaran Cooperative Learning. Metode Jigsaw dikembangkan dan diuji oleh Elliot Aronson dan kawankawannya. Dalam metode ini, siswa ditempatkan pada kelompokkelompok belajar heterogen beranggota tiga sampai enam orang (kelompok asal atau kelompok induk). Berbagai materi disajikan kepada siswa dalam bentuk teks dan setiap siswa bertanggung jawab untuk mempelajari satu porsi materinya. Selanjutnya para anggota dari kelompok-kelompok yang berbeda tetapi membicarakan topik yang sama (kelompok ahli atau kelompok expert) bertemu untuk belajar dan saling membantu dalam mempelajari topik tersebut. Setelah itu, siswa kembali pada kelompok induknya dan mengajarkan materi yang telah mereka pelajari dalam kelompok ahli kepada anggotaanggotanya di kelompok induk. Setelah pertemuan dan diskusi pada kelompok induk selesai, siswa mengerjakan kuis secara individu tentang berbagai materi yang telah dipelajari. Dalam hal ini peran guru hanya sebagai fasilitator dan mediator dalam proses pembelajaran IPS materi sejarah (Erna Agustina, 2003:67).

Pembelajaran Sejarah yang dalam jenjang Sekolah Menengah Pertama dimasukkan dalam Mata Pelajaran Ilmu Pengetahuan Sosial, diperlukan strategi, metode, teknik dan model pembelajaran yang tepat sasaran, disesuaikan dengan materi sehungga siswa dapat dengan mudah dan senang untuk memahami dan menghayati substansi materi pokoknya.Sebagian besar yang terjadi di lapangan, pelajaran Sejarah sangat membosankan karena Guru hanya menceritakan kembali peristiwa yang sudah terjadi dengan ceramah saja. Akibatnya antusias siswa dalam mengikuti pelajaran sejarah menurun dan ceramah yang digunakan Guru dalam menyampaikan materi menjadi pengantar tidur bagi siswa. Untuk itu diperlukan kreatifitas Guru dalam menentukan strategi, metode, teknik dalam menyampaikan materi dengan menguasai berbagai model pembelajaran. Siswa mempunyai karakteristik yang beraneka ragam sehingga diperlukan pelayanan yang berbeda pula. Sesuai dengan pendapat Uno ( 2007 : 1) bahwa 
Karakteristik siawa yang berbeda memerlukan metode pembelajaran yang berbeda pula.

Tujuan penelitian ini adalah untuk meningkatkan pemahaman siswa terhadap konsep-konsep dan kompetensi dasar Ilmu Pengetahuan Sosial melalui Cooperative Learning Jigsaw, tentang Berakhirnya Orde Baru dan Lahirnya Reformasi di kelas 9.3 . Metode yang digunakan dalam penelitian ini adalah metode kualitatif. Subjek penelitian ini adalah siswa kelas 9.3. Penelitian Tindakan Kelas ini mempunyai manfaat yang cukup besar bagi kemajuan dunia pendidikan dan bagi kemajuan prestasi sekolah pada khususnya. Karena terdapat masalah dalam hasil belajar yang masih dibawah KKM, kebenaran hipotesis tindakan kelas perlu didukung dengan data-data dan informasi akurat yang diperoleh melalui penelitian. Data dalam penelitian ini diperoleh dari tes hasil belajar yang dilaksanakan tiap siklus serta data dari lembar observasi guru dan angket siswa. Berdasarkan analisis sebelum penelitian, diketahui bahwa respon siswa tehadap Cooperative Learning Jigsaw tentang Ilmu Pengetahuan Sosial, positif.

\section{Metode Penelitian}

Metode yang digunakan dalam penelitian ini adalah metode kualitatif bersifat deskriptif analitis. Melalui penelitian ini, peneliti berusaha memahami dan menafsirkan suatu peristiwa menurut perspektif dan hasil pengamatan, sehingga penulis mendapat gambaran secara menyeluruh mengenai masalah yang diteliti. Penelitian dilaksanakan di SMP Negeri 16 Kota
Bogor pada awal pertengahan semester genap tahun pelajaran 2014/2015 yaitu tanggal 2 Maret 2015 sampai dengan 11 Maret 2015. Subjek penelitian adalah siswa kelas 9.3 SMP Negeri 16 Kota Bogor dengan jumlah siswa 38 orang yang terdiri dari 15 siswa laki-laki dan 23 siswa perempuan.Teknik pengumpulan data dalam penelitian ini adalah berupa observasi, tes dan studi dokumentasi.

Data yang dianalisis dalam penelitian ini adalah Kegiatan Pembelajaran yang dilaksanakan oleh Guru yang meliputi Apersepsiaktifitas siswa selama proses pembelajaran berlangsung yang semuanya diperoleh dari hasil observasi yang meliputi kehadiran peserta didik, keaktifan dalam bertanya, aktifitas siswa dalam menjawab pertanyaan dan aktifitas dalam memberikan argumen. Untuk mengukur ketuntasan hasil belajar digunakan Kriteria Ketuntasan Minimum yang dinyatakan tuntas apabila tingkat persentase ketuntasan minimalnya mencapai 75 dari skor maksimal 100. Penelitian ini dengan menggunakan prosedur penelitian tindakan kelas, yang menggunakan model modifikasi Depdiknas dari model Kemmis dan Taggart. Desain penelitian tersebut digambarkan sebagai berikut 


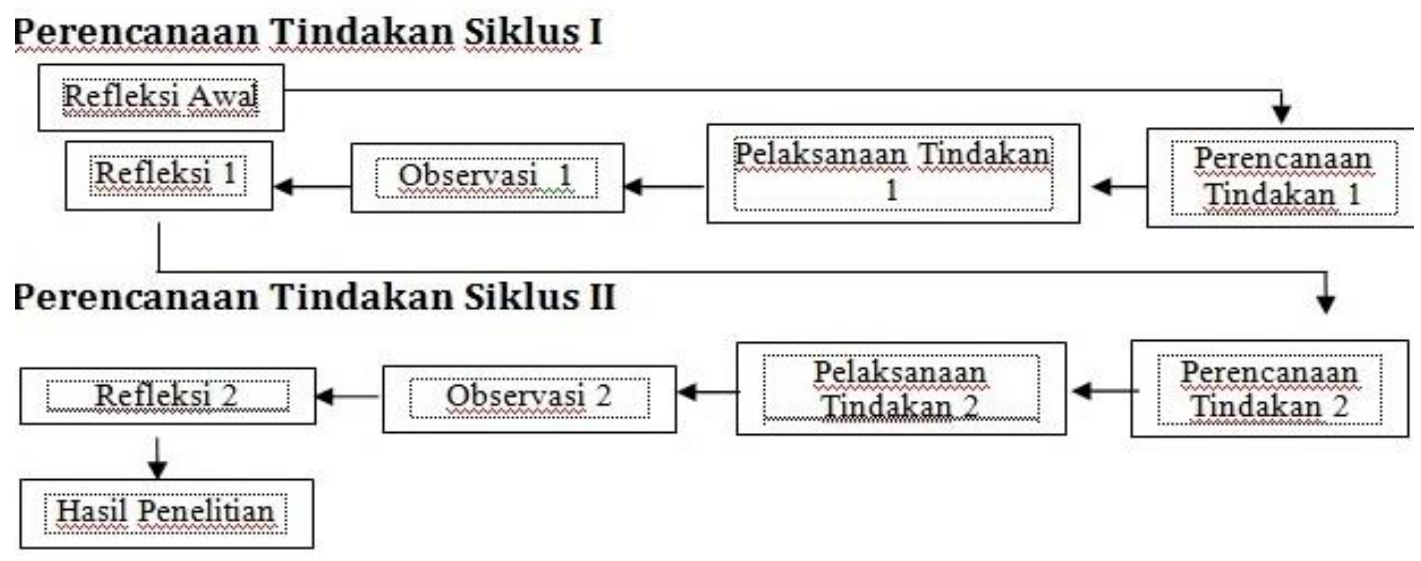

\section{Bagan Desain Penelitian Tindakan Kelas Model Modifikasi \\ Depdiknas dari Model Kemmis dan Taggart}

\section{Hasil Penelitian dan Pembahasan}

Hasil Observasi kegiatan pembelajaran yang dilakukan Guru pada siklus 1 masih terdapat kekuarangan dan perlu ada perbaikan. Kegiatan Guru pada siklus 1 dapat dilihat pada grafik berikut :

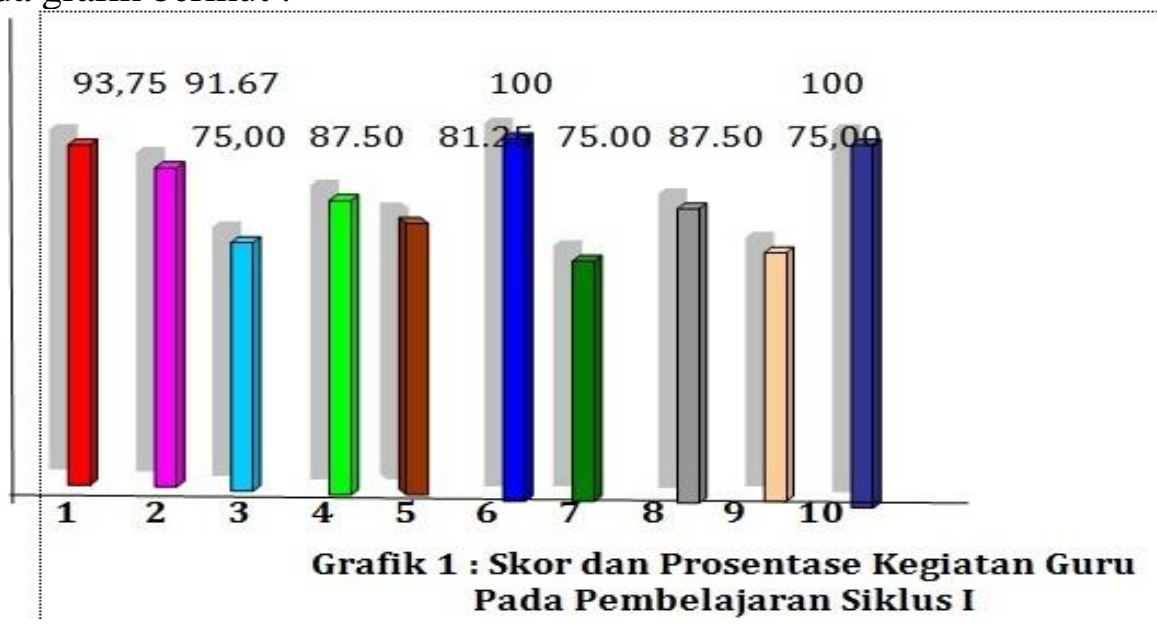

Guru dalam melaksanakan dilakukan oleh guru pada proses belajar pembelajaran kooperatif Jigsaw termasuk baik, hal ini dilihat dari perolehan skor 104 dari total nilai ideal 120 atau 86,67\%. Hal ini menunjukkan masih banyak kekurangan yang mengajar di siklus 1 , sehingga masih banyak kegiatan yang memiliki jumlah skor rendah.Perbaikan proses pembelajaran dilakukan oleh Guru pada siklus 2 sehingga memperoleh 
prosentase yang hampir sempurna yaitu $98,33 \%$ dari siklus 1 yang hanya tercapai 86,67\%. Hasil Belajar siswa mengalami kenaikan yang cukup signifikan dari perolehan nilai Pra siklus, siklus 1 dan siklus 2 .

Tabel 1

Data Perolehan Rata-rata Nilai Pra Siklus

\begin{tabular}{||c|c|c|r|c||}
\hline \hline \multicolumn{5}{|c|}{ PEROLEHAN NILAI PRA SIKLUS } \\
\hline Nilai & $\begin{array}{c}\text { Jumlah Peserta } \\
\text { didik }\end{array}$ & n.f & \multicolumn{1}{c||}{ Rata-rata } & \\
\hline 45 & 5 & 225 & 9,51 & $\mathrm{n}=\frac{\mathrm{n} \times \mathrm{f}}{\mathrm{n}}$ \\
50 & 4 & 200 & 8,46 & \\
55 & 3 & 165 & 6,98 & \\
60 & 3 & 180 & 7,61 & \\
65 & 6 & 390 & 16,49 & \\
70 & 14 & 980 & 41,44 & \\
75 & 3 & 225 & 9,51 & \\
80 & 0 & 0 & 0 & \\
85 & 0 & 0 & 0 & \\
90 & 0 & 0 & 0 & \\
100 & 0 & 0 & 0 & \\
\hline Jumlah & $\mathbf{3 8}$ & $\mathbf{2 3 6 5}$ & $\mathbf{1 0 0}$ & $\mathbf{6 2 , 2 3}$ \\
\hline
\end{tabular}

Tabel 2

Data Perolehan Rata-rata Nilai

Pada Siklus 1 dan Siklus 2

\begin{tabular}{||c|c|c|r|c|r|r|r|r||}
\hline \multicolumn{8}{||c|}{ Siklus ke-1 } & \multicolumn{1}{c||}{ Siklus ke-2 } \\
\hline Nilai & $\begin{array}{c}\text { Jml. } \\
\text { Peserta } \\
\text { didik }\end{array}$ & n.f & \% & $\begin{array}{c}\text { Rata- } \\
\text { rata }\end{array}$ & $\begin{array}{c}\text { Jml. } \\
\text { Peserta } \\
\text { didik }\end{array}$ & n.f & \% & $\begin{array}{c}\text { Rata- } \\
\text { rata }\end{array}$ \\
\hline 60 & 7 & 420 & 15,50 & - & 6 & 360 & 12,20 & \\
65 & 4 & 260 & 9,60 & - & 0 & 0 & 0 & \\
70 & 8 & 560 & 20,66 & - & 5 & 350 & 11,86 & \\
75 & 11 & 825 & 30,44 & - & 0 & 0 & 0 & \\
80 & 7 & 560 & 20,66 & - & 19 & 1520 & 51,53 & \\
85 & 1 & 85 & 3,14 & - & 0 & 0 & 0 & \\
90 & 0 & & 0 & - & 8 & 720 & 24,41 & \\
95 & 0 & & 0 & - & 0 & 0 & 0 & \\
\hline Jumlah & $\mathbf{3 8}$ & $\mathbf{2 7 1 0}$ & $\mathbf{1 0 0}$ & $\mathbf{7 1 , 3 2}$ & $\mathbf{3 8}$ & $\mathbf{2 9 5 0}$ & $\mathbf{1 0 0}$ & $\mathbf{7 7 , 6 3}$ \\
\hline \hline
\end{tabular}




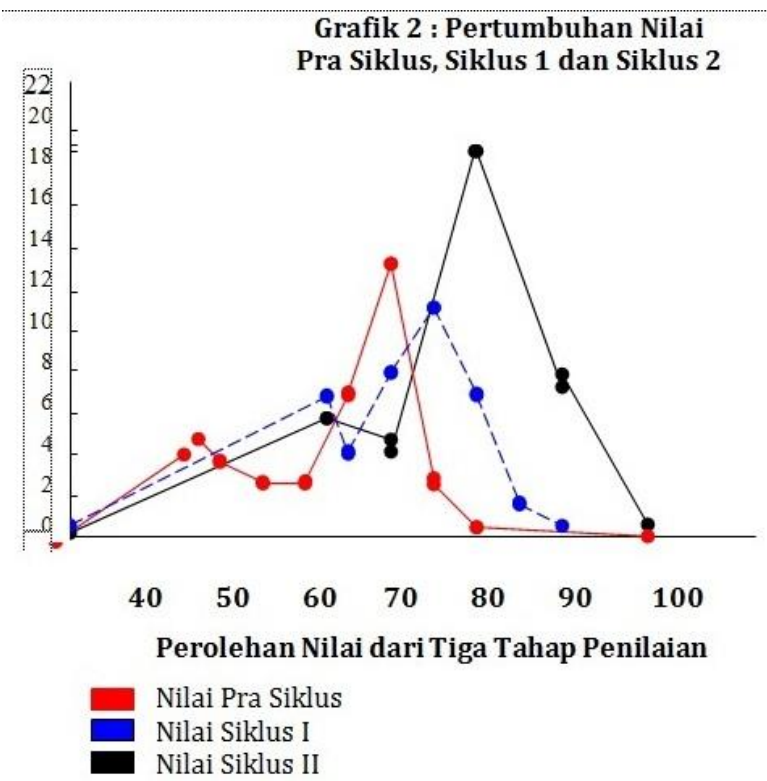

Berdasarkan hasil pengolahan data dan observasi terlihat adanya perubahan nilai rata-rata kelas yang cukup baik pada proses pembelajaran yang telah dilaksanakan, hal ini dibuktikan dengan hasil nilai rata-rata yang semula 62,23 (pra siklus) menjadi 71,32 pada hasil pembelajaran siklus 1 dan 77,63 pada hasil pembelajaran siklus 2. Kemudian hasil pengamatan terhadap aktivitas, terjadi perubahan sikap yang cukup menggembirakan, yaitu peserta didik mulai berani dan aktif bertanya, berinteraksi dengan teman sekelasnya, perhatian yang fokus serta aktif menjawab pertanyaan.

Jumlah siswa yang mampu menguasai materi di atas KKM yang ditetapkan sekolah yaitu 75, pada akhir siklus 2 sebanyak 27 orang atau $71,65 \%$. Kegiatan guru dalam proses belajar mengajar ada perbaikan, hal ini terllihat dari skore rata-rata yang diperoleh Guru pada siklus 1 adalah $86,67 \%$ sedangkan pada siklus kedua menjadi $98,33 \%$, ada kenaikan yang signifikan dari nilai baik menjadi amat baik. Kenaikan diperoleh dari beberapa kegiatan yaitu asalnya $75,00 \%$, kemudian pada kegiatan pembelajaran dengan model Jigsaw menjadi 100\%.

Pada kegiatan memberikan penghargaan pada siswa ada kenaikkan sedikit yaitu dari $75,00 \%$ menjadi $100 \%$, pada kegiatan apersepsi $93,75 \%$, karena Guru masih dianggap kurang jelas dalam menjelaskan aturan diskusi. Berdasarkan hasil observasi terhadap siswa dan guru pada tingkatan pra siklus, aktifitas guru dan siswa masih banyak kekurangan. Guru masih belum maksimal dalam mengelola waktu saat pembelajaran, sehingga proses pembelajaran cenderung tidak tuntas, yang berakibat tidak semua siswa dapat aktif mengikuti proses pembelajaran. Oleh karena hal tersebut, masih ada sebagian siswa yang sempat melakukan kegiatan yang tidak sesuai dengan tujuan pembelajaran. Untuk 
memperjelas pembahasan setiap siklus, disajikan tabel rekapitulasi dibawah ini :

Tabel Rekapitulasi Hasil Penelitian Siklus 1 dan siklus 2

\begin{tabular}{|l|l|l|l|l|l|}
\hline \multirow{2}{*}{$\begin{array}{l}\text { Aspek Yang } \\
\text { Dinilai }\end{array}$} & \multicolumn{4}{|c|}{ Hasil Belajar } & \multirow{2}{*}{ Ket } \\
\cline { 2 - 5 } & \multicolumn{2}{|c|}{ Siklus 1 } & \multicolumn{2}{c|}{ Siklus 2 } \\
\cline { 2 - 5 } & Nilai & Makna & Nilai & \multicolumn{1}{|c|}{ Makna } & \\
\hline $\begin{array}{l}\text { Pengelolaan } \\
\text { Pembelajaran }\end{array}$ & $86,67 \%$ & $\begin{array}{l}\text { Sangat } \\
\text { Baik }\end{array}$ & $98,33 \%$ & $\begin{array}{l}\text { Sangat } \\
\text { Baik }\end{array}$ & $\begin{array}{l}\text { Meningkat } \\
11,66 \%\end{array}$ \\
\hline $\begin{array}{l}\text { Aktifitas } \\
\text { Peserta Didik }\end{array}$ & $57,89 \%$ & Kurang & $70,17 \%$ & Baik & $\begin{array}{l}\text { Meningkat } \\
12,28 \%\end{array}$ \\
\hline $\begin{array}{l}\text { Ketuntasan } \\
\text { Hasil Belajar }\end{array}$ & $50,00 \%$ & Kurang & $71,05 \%$ & Baik & $\begin{array}{l}\text { Meningkat } \\
21,05 \%\end{array}$ \\
\hline $\begin{array}{l}\text { Nilai rata } \\
\text { Rata }\end{array}$ & 71,32 & Baik & 77,63 & Baik & $\begin{array}{l}\text { Meningkat } \\
6,31\end{array}$ \\
\hline
\end{tabular}

Hasil dari penelitian tentang Pengelolaan pembelajaran menunjukkan adanya peningkatan kualitas dari hasil siklus 1 memperoleh 86,67 \% meningkat $11,66 \%$ pada siklus 2 menjadi 98,33 \% dengan interpretasi sangat baik. Perubahan aktifitas peserta didik dalam kehadiran, keberanian bertanya, menjawab pertanyaan dan memberkan agumen atau ide idenya juga mengalami peningkatan sebesar $12,28 \%$ dari hasil $57,89 \%$ dengan kualifikasi Kurang pada siklus 1 meningkat menjadi 70,17 \% dengan interpretasi Baik. Ketuntasan Belajar dimana siswa harus mencapai nilai KKM yang sudah ditentukan yaitu 75 , juga mengalami peningkatan dari 19 siswa yang mencapai KKM pada siklus 1 yaitu sebesar $50 \%$ meningkat menjadi 27 siswa atau 71,05 \% siswa telah mencapai KKM yang ditetapkan sekolah.Dalam hal ketuntasan belajar ini terjadi peningkatan sebesar $21,05 \%$. Sementara dari hasil nilai rata rata yang diperoleh pada saat tes formatif diperoleh rata rata sebesar 71,32 pada siklus 1 dengan interpretasi baik dan mengalami peningkatan sebesar 6,31 menjadi 77,63 dengan interpretasi baik.

Perubahan prosentase dan meningkatnya hasil berbagai aspek tersebut menunjukkan adanya ketuntasan hasil belajar pada materi Berakhirnya Orde Baru dan Lahirnya Reformasi di kelas 9.3 walau baru tercapai $71,05 \%$ dalam penelitian selama 2 siklus. Namun demikian sudah dapat disimpulkan bahwa penggunaan model Jigsaw dalam pembelajaran cooperatif Learning berhasil meningkatkan pemahaman siswa tentang materi yang disampaikan. Hasil observasi pada siklus 1, siswa menunjukan peningkatan yang baik dalam proses pembelajaran. Keaktifan siswa meningkat dari proses pembelajaran sebelumnya, siswa mulai fokus perhatiannya saat mengikuti pelajaran di kelas. Perkembangan baik tersebut, siswa sebagian besar sudah mampu mengerjakan tugas dengan baik dan nilai rata-rata kelas maupun nilai individu hasil belajar siswa meningkat. 
Hanya saja dalam pembelajaran siklus 1 ini guru dianggap masih belum profesional dalam mengelola waktu yang tersedia. Begitu pula dalam siklus 2 , kinerja guru dalam proses belajar mengajar sudah menunjukkan profeionalismenya dalam mendidik siswa.

Berdasarkan hasil wawancara terbuka dengan siswa mengenai model pembelajaran yang telah dilaksanakan, siswa berpendapat bahwa model pembelajaran Jigsaw lebih mempermudah siswa dalam mengingat dan memahami materi pelajaran yang dijelaskan guru. Siswa merasa cocok dan senang saat belajar, karena siswa diberikan kebebasan untuk mengemukakan pendapatnya atau mendiskusikan kesulitan saat menemukan hal-hal yang belum dipahaminya. Pembelajaran Kooperatif Model Jigsaw yang telah dilaksanakan dapat meningkatkan pemahaman dan hasil belajar siswa, karena dengan menggunakan pembelajaran model ini siswa terlihat lebih aktif dalam belajar, kegiatan belajar lebih menarik dan tidak membosankan.

\section{Penutup}

Berdasarkan pembahasan hasil penelitian yang dilakukan, dapat ditarik kesimpulan bahwa penerapan cooperative learning model Jigsaw dapat meningkatkan pemahaman siswa sehingga terjadi peningkatan hasil belajar pada mata pelajaran Ilmu Pengetahuan Sosial di Kelas 9.3 Sekolah Menengah Pertama Negeri 16 Kota Bogor pada semester genap tahun pelajaran 2014-2015. Cooperative Learning Model Jigsaw dapat meningkatkan kemampuan siswa untuk memahami lebih luas tentang konsep Berakhirnya Orde Baru dan Lahirnya Reformasi. Hal ini ditunjukan dengan perolehan nilai rata-rata kelas yang makin meningkat dari setiap siklusnya. Cooperative Learning Model Jigsaw telah mampu meningkatkan dan memotivasi keaktifan siswa dalam proses pembelajaran, khususnya pada mata pelajaran Ilmu Pengetahuan Soaial ( IPS ) tentang Berakhirnya Orde Baru dan Lahirnya Reformasi. Respon siswa di awal penelitian, positif. Hal tersebut telah terbukti melalui Penelitian Tindakan Kelas yang telah dilaksanakan, dengan perolehan nilai rata-rata siswa yang mengalami perbaikan yang cukup signifikan pada setiap siklusnya.

\section{Ucapan Terimakasih}

Dalam kesempatan ini, penulis mengucapkan terimakasih kepada berbagai pihak yang telah membantu terlaksananya penelitian tindakan kelas ini, sejak dimulainya penelitian, penyusunan hasil penelitian dan publikasi .Tidak lupa pula, ucapan terima kasih penulis sampaikan kepada dewan redaksi Jurnal Istoria yang diterbitkan oleh Fakultas Ilmu Sosial Universitas Negeri Yogyakarta atas kesempatan, bantuan dan kerjasamanya yang tidak terhingga sehingga hasil penelitian ini dapat dipublikasikan pada edisi Maret 2017.

\section{Daftar Pustaka}

Erna Agustina, dkk. 2013. "Penggunaan Metode Pembelajaran Jigsaw Berbantuan Handout untuk Meningkatkan Aktivitas dan 
Prestasi Belajar Siswa”. Jurnal Pendidikan Kimia. Surakarta: Universitas Sebalas Maret.

De Porter, Bobbi \& Mike Hernacki.2000.Quantum

Teaching.terjemahan Alwiyah Abdurraahman.Bandung : Kaifa

Hamalik, Oemar. 2011. Mengajar Metode Tekhnik. Jakarta: Bumi Aksara.

Hamdani,Nizal Alam dan Hermana, Dody.2008.Classroom Action Research.Bandung : Rahayasa.

Huda, Mifhatul. 2013. Model-model Pengajaran dan Pembelajaran. Yogyakarta: Pustaka Pelajar.

Lie, Anita. 2014. Cooperative Learning, Mempraktekkan Cooperatif Learning di Ruang ruang Kelas. Jakarta: Grassindo.

Sukarnyana, Wayan, I. 2002.Penelitian Tindakan Kelas. Malang : Departemen Pendidikan Nasional,Direktorat Jenderal Pendidikan Dasar dan Menengah, Proyek Peningkatan Pusat Pengembangan Penataran Guru IPS dan PMP Malang.

Susanto, Ahmad. 2013. Teori Belajar dan Pembelajaran. Bandung: CV.Pustaka Cendikia Utama

Sutikno, Sobari. 2007. Strategi Belajar Mengajar. Bandung: Refika Aditama.

Undang, Gunawan.2008. Teknik Penelitian Tindakan Kelas. Jakarta : Sayagatama.

Wibawa, Basuki.2003.Penelitian Tindakan Kelas. Jakarta : Departemen Pendidikan Nasional,Direktorat Jenderal Pendidikan dasar dan
Menengah, Direktorat Tenaga Kependidikan.

Uno, B. Hamza. 2007. Model Pembelajaran Menciptakan Proses Belajar Mengajar yang Kreatif dan Efektif. Jakarta: Bumi Aksara 